ing, I think, commends such a proposition and not the one about "common sense" being on the side of "joining the Union" and "winsome superstition" on the side of resistance to such views. Few will consciously argue that citizenship in a certain country is an ipso facto basis for moral superiority. (Let me add, however, that only the naive will believe that choosing or maintaining a citizenship is an act that has no moral ramifications.

2. The second comment can be made much more briefly. Ignorance on the part of a neighbor is a fault that I carefully nurture if he is an enemy and most readily forgive if he is a friend.

What am I then to think of Mr. Neuhaus? First, I might suggest that, when he rests his eyes on the banks of the Ottawa and wishes to write, he should turn to a genre other than social comment. His adherence to rules of evidence is much too relaxed when he is in such circumstances. He might also pay some attention to studies of nationalism. Not all nation-building follows the same path, nor fulfills the same needs, nor meets the same challenges. (Not all nations, for instance, become one largely through the proclamation of a doctrine addressed to themselves and to the rest of the world.) He might also reexamine yet once again, alas, the case of those critics who charge that there is a strange blindness common among U.S. social scientists and moral prophets. Their science is sophisticated and their hearts pure; they rush, therefore, to think Americanly and benevolently about the rest of the world; again and again they are met with at best an ambivalent response that creates a hurt and opens a gulf. But look at it from our point of view: We do not like always being invited to be friends on your terms.

Such reflections, I realize, are fairly trite. They have another great disadvantage: They usually launch many non-Americans into anti-American intellectuality, and quite a few American intellectuals into fits of self-doubt. There is no health in these kinds of mental joyrides. So 1 cannot derive any pleasure from my concluding reflections. I will, therefore, make my final point in more personal terms. It does little honor to $\mathrm{Mr}$. Neuhaus to publish in Worldview a piece which uses the information and the tone he has chosen. His humor turns too quickly into sarcasm. It is not funny to see him poke fun at all our political life. His own ties to the country are no excuse. These ties are the accidental ones of birth and upbringing. The ties of affection that he feels are nostalgic and sentimental, it seems to me. The group of people one really loves is the one with whom one lives the struggles of one's maturity.

\section{Professor of Religion}

Michel Despland

\section{Concordia University}

\section{Montreal}

Richard John Neuhaus Responds:

M. Despland's splendid and chastening letter highlights once again the dangers in trying to be funny. I find myself in a "damned-if-you-do/ damned-if-you-don't" dilemma similar to the one Despland says he is placed into by my remarks on Canadian thought being "reactive." That is, if I take up Despland on his arguments, I might be accused of giving the lie to the whimsical intent I attribute to the original article. Ah well, like Despland, let me muddle on in the hope of breaking out of the dilemma, if only by chance.

M. Despland's correction about Newsweek hardly seems substantive. By whatever name, "tax privilege" is the power to control, in this case to control competition. As for the pressures to learn French, the distinction between "social reward" and "legal coercion" is fragile at best. The point is that, and in part because of the law, if you want to get ahead you better learn French, also in Saskatchewan. As to the schools, there is nothing wrong with the law favoring one language over another. The "democratic notion" is that people ought to be able to choose for themselves and their children, a right sharply inhibited by Bill 22 in Quebec. I agree wholeheartedly with $M$. Despland that the desirable alternative is definitely not the "totalitarian" school policy that still prevails in the United States. Contra Despland, I reserve the right to "really love" both Canada and the United States, for it is among both peoples that I am living out the struggles toward maturity.

Finally, and for what little it may be worth, I suspect $M$. Despland and I are not so far apart. His return address, I note, is a boulevard named Maisonneuve (new house, Neuhaus).

\section{Food Enough for All?}

To the Editors: I have just read the September, 1975, Worldview article "Food Enough for All" by David Harmon and Marylin Chou and must make the following comments:

1. Harmon/Chou appear to have written their article within the sterile confines of Croton-on-Hudson. I refer particularly to their paragraphs about the so-called successful Philippines' "'Masagana 99" program. Their recitation of Marcos's New Society data is theoretically profound but realistically naive.

A closer look at the current Philippine scene would indicate that the proposed Land Reform program brought about by Marcos's New Society is a boon for sugar plantation owners. Land much needed for rice and other crops is being used for expanded sugar fields-at low yields for the grower and even less usable food for the average Philippine citizen.

Had Harmon/Chou taken seriously the plight of the Philippine citizen, they would know that even the price of rice is getting further and further beyond the reach of these good folk.

2. My point is simply this: that Harmon/Chou fall victim to the false hope that "profit" will enable an abundance of food for the world. It is not working so in the Philippines, nor is it for the rest of the world.

The first and most important incentive for food production is not profit but the sacredness and beauty of human life. When these factors are relegated to second place, we will simply not be able to deal realistically with the problem of food production.

The gap between rich and poor continues to widen. So does the gap between researchers and realism.

North Point, Hong Kong

$$
\text { Ewing W. Carroll, Jr. }
$$

David P. Harmon, Jr., and Marylin Chou Respond:

Let us start with Mr. Carroll's second and more important point, that "profit" offers false hope. One of the key requirements in developing-country 